\title{
THE LOST HERITAGE OF ROMAN IRON AND STEEL BRIDGES. VIRTUAL RECONSTRUCTION OF TWO CASE STUDIES
}

\author{
R. Morganti ${ }^{1 *}$, A. Tosone $^{1}$, M. Abita ${ }^{1}$, D. Di Donato ${ }^{1}$, \\ ${ }^{1}$ Dept. DICEAA, Department of Civil, Construction-Architectural, Environmental Engineering, University of L'Aquila, Italy, \\ renato.morganti@univaq.it, alessandra.tosone@univaq.it, matteo.abita@univaq.it, danilo.didonato@univaq.it
}

Commission II, WG II/8

KEY WORDS: Bridges, Rome, Iron and steel structure, virtual reconstruction, lost heritage

\begin{abstract}
:
In the second half of $19^{\text {th }}$ century the city of Rome knew a period of great urban transformations: the Pope Pio IX and after, the government of the new Kingdom of Italy, strongly pushed the modernization of the ancient and underdeveloped city, trying to follow the examples of the main European capitals. One of the most relevant signs of that period was the construction of multiple iron and steel bridges along the Tiber, that were built to improve the crossing network guaranteed by the old masonry links. Different supporting systems were used and many experimental technologies for the Italian context were tested, representing a crucial phase for the settle of a design and an industrial know-how that was firstly imported from the most advanced countries of the Northern Europe.

In the $20^{\text {th }}$ century most of these connections were unfortunately replaced, losing this precious heritage which was strongly linked to the technological culture of the time. Garibaldi Bridge, still present but radically transformed, and Alari Bridge, completely demolished, have been accurately modelled thanks to the availability of appropriate archival documentation and on-site tests, applied following a proposed methodology. The virtual reconstruction of the two case studies permits to spread the knowledge of this lost heritage, to ease the divulgation of past technologies and to recover the unusual image of exposed iron and steel structures surrounded by the ancient panorama of the Eternal city.
\end{abstract}

\section{INTRODUCTION}

Two young spouses gloomily greet each other by the banks of a river that divides the city and marks the border between two nations (Figure 1). The scene from the movie "The suspended step of the stork", directed by Theo Angelopoulos, expresses the paradox and the "melancholia" of separation (Horton, 1999).

Suppose now that we replace the Greek director and we shoot the same scene introducing a bridge between the two banks in order to connect them, making possible the union of the spouses. Then the artifice of the bridge would turn the scene from the intrinsic melancholy that Angelopoulos seeks, to the joy of the meeting that finally come true. Therefore the bridge assumes a value that is not only physical and spatial, but it rises to a metaphor of what overcome distances, linking something that was previously separated (Cassani, 2014). The transcendent character perhaps represents an unpredictable trait at the time of its construction, but it historically signifies it reaffirming the fundamental importance in the landscape construction. The absence of a bridge is even more marked if it is amplified by memory. Indeed the bridge can be a weak object; more often the environmental conditions, the carelessness or the willingness of men to declare its end, drastically reduce its duration, leaving only the memory that brings with it the melancholy of absence. The memory, however, is itself "weak" and the years erase the traces of the past or accumulate on them "the dust of time"; so as to lose also memories and successive generations tend to forget what it was before. This is what happened, for example, to the iron bridges of the 19th century in Rome, a heritage that is now lost but which represented a turning point in the process of modernization of the papal city and in the construction of the new capital, generating a radical "change of direction" in the antiquated technological context of the city.

The main goal of the contribution consists of attempting a possible recovery, with a view to establishing "new bridges" with the past, bringing to light the events linked to the construction of Roman iron bridges of 19th and 20th centuries, not only to preserve their memory, but also to guarantee a reconstruction, virtual and not real, that could make present and future generations aware of an important episode in the urban history of the Eternal City. This heritage has been soon forgotten, also due to the missed recognition, in Italy, of the expressed values and to the difficult sharing of the condition of "historicity", not yet codified for the outcomes reached by iron construction from the second half of 19th century (Casciato, 2017).

If the tangible heritage is irremediably lost, the contribution intends to propose the recovery of the immaterial and intangible one; resorting to contemporary digital tools that work as a support to the process of historical-architectural re-enactment of the examined bridges, with a view to placing them, progressively and in the wake of a work that is not yet concluded, within the historical contexts that once hosted them. The potential of this approach - extensively analysed by several authors (Di Mascio and Pauwels, 2014; Quattrini et al. 2016) but open to further developments - can constitute a synthesis, even partial, of the results of the modeling allowed by the current tools of augmented reality (Rushton et al. 2018) - in particular, the panorama of images that it proposes to restore the morphology of the represented objects - and the historical significance that is related to them and which means their intrinsic intangible heritage (Guidi and Russo, 2011).

The relationship between image and history seems to find, in the field of computer graphics, a different variation, passing from the traditional approach that recognized the image as a document, assumed for its the visual testimony as historical source, to the current behaviour for which the image is considered as a virtual representation, able to take in itself material and immaterial values, reproducing history according to a re-edition that is not false or simulated, but potential

\footnotetext{
* Corresponding author
} 


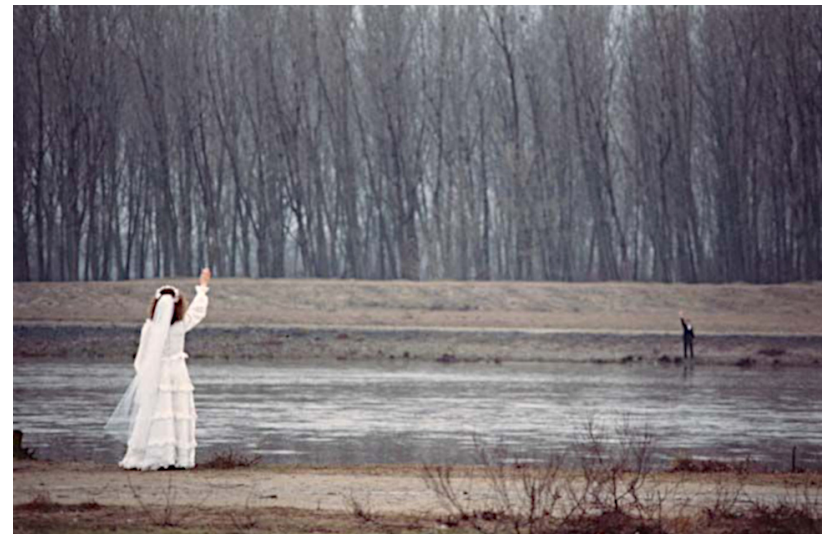

Figure 1. Frame of the movie "The suspended step of the stork" (Angelopoulos, 1991)

(Lévy, 1995). Therefore the reconstruction of the lost heritage of the iron bridges of Rome represents the re-enactment of a crucial part of its urban history, included in the general events that mark the sudden metamorphosis from the Capital of the Papal State to the Capital of the new Savoy Kingdom.

\section{LOST HERITAGE OF IRON AND STEEL BRIDGES OF ROME}

In the middle of $1800 \mathrm{~s}$, Rome seems to be a city stopped in time, indifferent to economic and social transformations of the greatest European cities. In 1846 Pio IX, aware of this condition, intervenes with a series of acts on administrative and urban plan, supplying the city of necessary infrastructures for its functionality (Spagnesi, 1997). This extraordinary plan intends to refurbish Tiber banks and realize the first rail network.

Metal construction plays a pivotal role in this affair: new bridges are built with ferrous materials, with projects and technology, which are imported from France and Belgium due to the underdevelopment of iron industries. Urban development project promotes an exceptional collaboration between Italian and foreign engineers, condition that is marked by the construction of three iron bridges along the Tiber.

In 1847 the Duke Pio Braschi Onesti founds the Suspension Iron Bridges Company, whose management is given to Camillo Montgolfier Boudin (Archivio di Stato di Roma, 1860). The company is authorised to build four suspension bridges along the Tiber, whose cost would have been recovered by the payment of a toll, but bureaucratic and legal difficulties will permit the construction of only two bridges.

The first intervention concerns the refurbishment of "Pons Aemilius", one of the oldest masonry bridges in Rome, known as "Broken Bridge" or "Senate Bridge". The French engineer

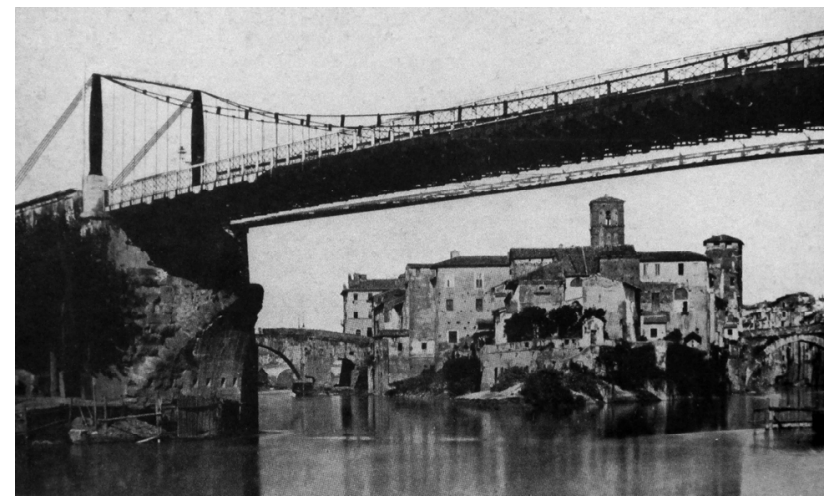

Figure 2. Broken Bridge near Tiber Island (Jodice, 1985)

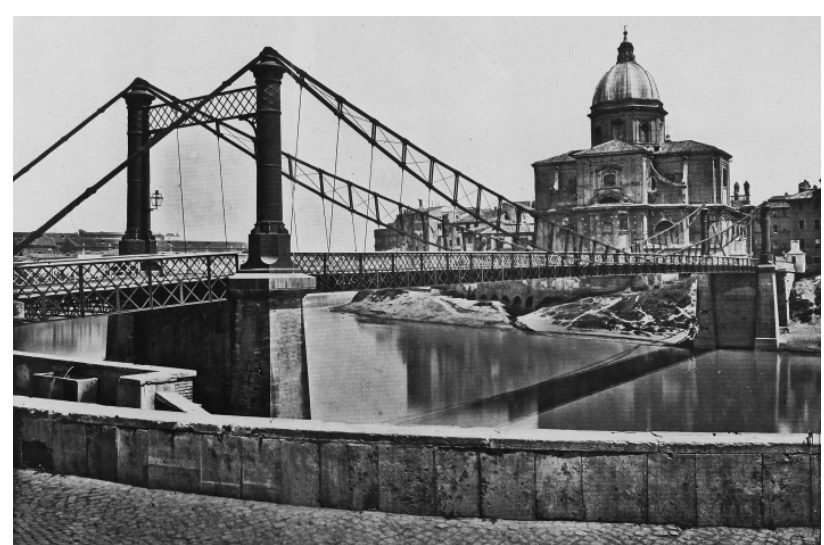

Figure 3. The suspension bridge near to the Church of San Giovanni dei Fiorentini (D’Onofrio, 1980)

Dumont and the engineer Pietro Lanciani, design a suspension iron bridge that links existing masonry arches with Aventino embankment (Cacchiatelli and Cleter, 1865). The metal structure consists of a couple of tapered columns and on their head it is placed the suspension system, characterised by jointed chains and suspenders under tension, that support a metal deck, which is 6 meters wide and 63 metres long (Figure 2).

Ten years later Boudin's company realises another suspension bridge, in the river section facing San Giovanni dei Fiorentini Church, designed by Alphonse Oudry with Paolo Cavi and Raffaele Canevari, The suspension system is more complex than the previous one and it uses for the first time not only iron elements, but also steel components, fabricated in England (Figure 3). The bridge shows two lateral bays and a central one, which is suspended by a system of chains, anchored at the ends to a couple of portals. The suspension system consists of chains to which are linked inclined suspenders reinforced by trusses supporting wood deck panels (D'Onofrio, 1980). Both realisations of "Suspension Iron Bridges Company" suffered a similar fate: Broken Bridge and its suspension iron structure is demolished in 1887, because of refurbishment of Tiber and Fiorentini Bridge is dismantled in 1941 in order to recover iron components that could be useful for wartime industries.

For the realization of the rail network in the area of "Termini", the construction of a bridge between Ostiense and Papareschi riverbanks is required. The Industry Bridge, designed by the Louis Hach and built with materials that are imported from Britain, is realized by a Belgian company under the direction of Leopoldo Brockmann, Francesco Barthelemy and Paolo Cavi. It is composed of three spans, two of them are fixed on the sides, instead the central one, movable, allowed the transit of ships to the near Ripa Grande harbour. The columns, sixteen metal tubes, realised with the method of compressed-air

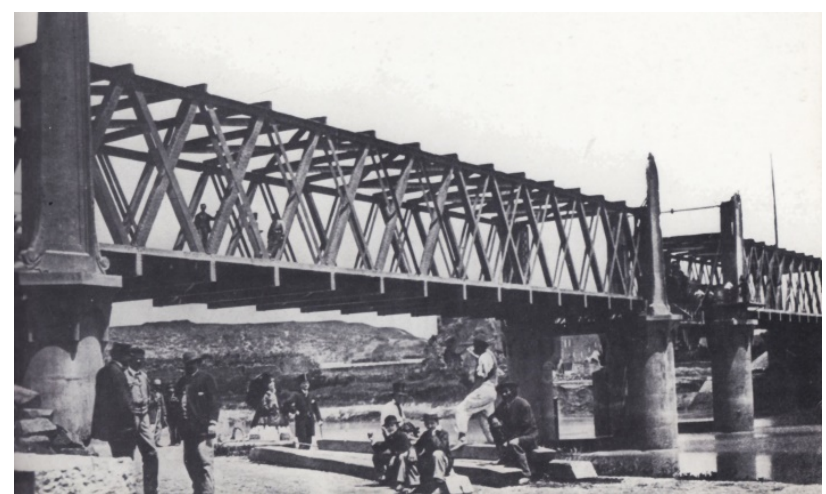

Figure 4. Industry Bridge at Ostiense quartier (Testa, 2007) 


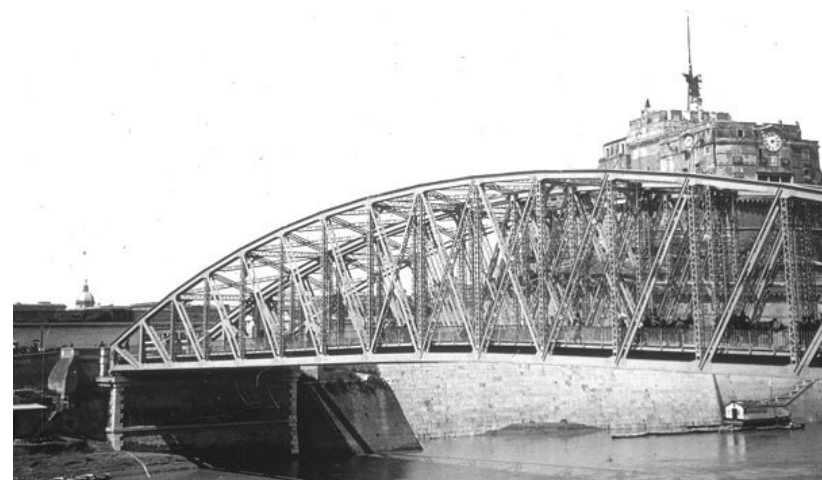

Figure 5. The temporary Alari Bridge near Castel Sant'Angelo (Postcard, 1899)

caisson, are filled with stones and completed on the head by decorated metal capitals (Figure 4). On the model of "tubular iron bridges", the lateral girders show lateral trusses composed of upper and lower chords with criss-crossed diagonal braces. Lateral trusses are athwart linked and they finish at the abutments on sturdy lattice columns (Jodice, 1985). The Industry Bridge, the only one between Papal States bridges which isn't removed, is affected by several transformations: it will preserve only the lower columns (Testa, 2007), instead the upper part will be replaced by two bowstring trusses, built with steel components of the provisional Alari Bridge (Figure 5).

In 1870, Rome becomes the capital of Kingdom of Italy. In the first municipal council nominates it is composed a group of architects and engineers, addressed for the enlargement and improvement of the city.

In the same year Rome, after an exceptional Tiber overflow, the authorities decide to start refurbishing the riverbanks. The engineer Raffaele Canevari promotes the realisation of high side walls, named "muraglioni", which irremediably modify the previous relationship between the city and the river.

In the 1883 the second urban plan of Alessandro Viviani "considering that the present bridges are insufficient to the need." promotes the construction of six new bridges, the refurbishment of Broken Bridge and the enlargement of connections near the Tiber Island.

In 1877, Cahen d'Anvers family, starts building a temporary pedestrian crossing between the left bank of the Tiber and the new district, close to the area of Ripetta Harbour (Figure 6). About Ripetta Bridge, Cottrau's company, Industrial Italian Company of Metal Construction (IIICM), realises eight tubular columns, using the same technique of compressed-air caisson, already experimented for the Industry Bridge, with some differences (Cottrau, 1878). The columns support a horizontal deck, composed of parapet lattice girders, connected by equidistant truss joist. The bridge execution, reached with the collaboration of engineer Francesco Kossuth, are completed in

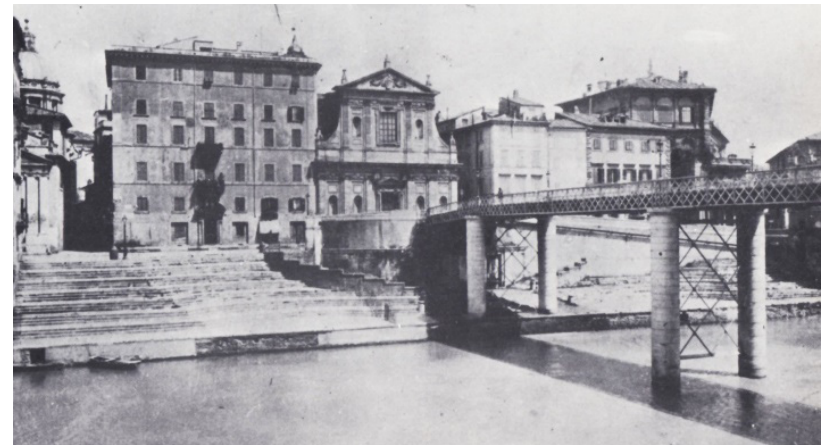

Figure 6. Ripetta Bridge and the old harbour (Cottrau, 1878)

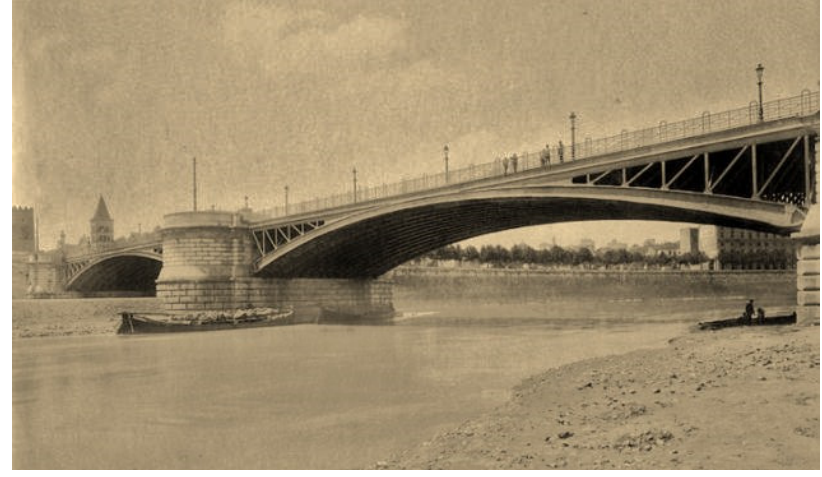

Figure 7. The slender arches of Garibaldi Bridge placed in the north side of Tiber Island (Vannelli, 1979)

1878 (Carughi, 2003). In 1901, after the completion of Cavour Bridge, the municipality decides to remove Ripetta Bridge moving its metal structure in the Magliana area. This intervention involves a radical transformation: the bridge is "cut" in two segments separated by a central draw-bridge which allows the transit of the ships. It, seriously damaged with Second World War bombing, will definitely be demolished after 1944. For the new Magliana Bridge, built of reinforced concrete, the steel is used only for the central movable span.

Between the six bridges planned only two are involved in the executive regulation of municipal government: Garibaldi Bridge, both designed by the Water Municipal Office directed by Angelo Vescovali. Garibaldi Bridge, "the greatest one built in Italy for the transit in ordinary way" (Vannelli, 1979), placed on the north end of Tiber Island, is composed of masonry abutments, a central masonry column, and two open sprandel metal arches (Figure 7). The realisation of the bridge is given to C. Zschokke \& P. Terrier Company.

About the foundation system of the columns and abutments, the compressed-air system permits the realisation of metal caissons built before the column sinking. The supply of material for the construction of metal arches and deck elements, arrive from Trady \& Benech Industries of Savona, that experiment for the first time in Italy the processes for the beam punching, using drills produced by Bouhey Company and for the riveting, using hydraulic machines supplied by Fielding \& Platt Company (Bonato, 1889). Garibaldi Bridge, inaugurated in 1888, has been used until 1950s, indeed after some load tests caused by the increase of car transit, a structural intervention, designed by Giulio Krall, radically modify its iron appearance.

For the second bridge, Vescovali choses a scheme of a continuous beam bridge with six supports: two abutments integrated with the riverbank walls and four columns placed in the riverbed (Figure 8). The bridge is built again by Zschokke \& Terrier Company that, on this occasion, charges IIICM for the realisation of metal girder (Bonato, 1891). About the

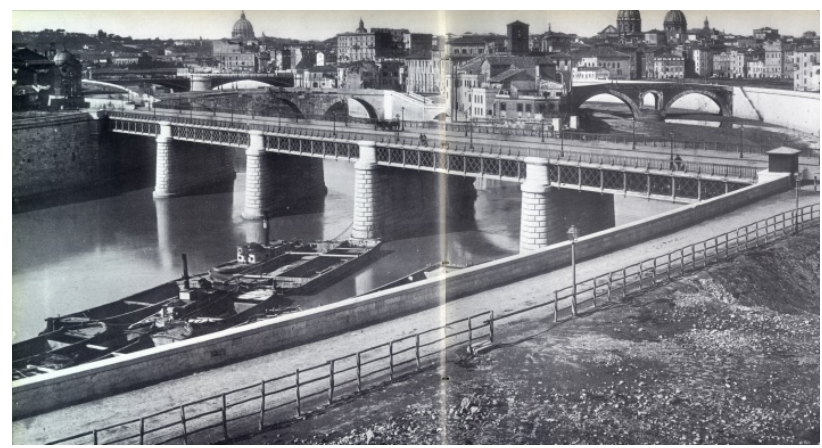

Figure 8. Palatino Bridge and the view of the city (Jodice, 1985) 
foundations, a pneumatic system is used for the sink of metal caissons. The six beams that compose the whole metal girder have different length and also their span is not regular because of the slanting axis of the bridge and the column positioning. They are composed of reinforced profiles, characterised by two webs for the internal beams, and a single web for the others. The execution starts in 1886 and it is completed only in 1890 .

\section{THE PROCEDURE APPLIED FOR THE VIRTUAL RECONSTRUCTION OF BRIDGES}

The definition of a procedure, expressly addressed to the digital reconstruction of a peculiar patrimony such as the iron bridges in the young Italian Capital - largely lost or completely transformed - requires a flexible and adaptive approach, suitable for including case studies which are particularly meaningful of the historical events phenomenology. The comprehension of developments that took place in these architectures during the period from their construction to demolition or transformation processes, involving one or more phases, represents the fundamental step for the definition of a general strategy, specifically defined and appropriate for the achievement of optimal reliability of three-dimensional models (Di Mascio et al. 2016).

In order to define a case system which include several phenomenological manifestations, related to the sequence of events, a crucial aspect consists in the recognition of a taxonomic classification for the constitution of different families which have to be pertinent to the analised bridges.

As a consequence of the previous step, six different modalities can be identified: the first occurs when a bridge has been demolished but an exhaustive documentation concerning its design and construction is available, which makes possible a reliable virtual reconstruction (a1) (Kouimtzoglou et al. 2017); a second, when a bridge has been demolished and primary and secondary sources aren't suitable for the virtual modeling (a2) (Apollonio et al. 2017); a third occurs when a bridge has been transformed but the availability of primary and secondary sources allows the reconstruction of its original configuration (a3) (Berthelot et al. 2015); a fourth, when a bridge has been involved in transformation processes and its historical documentation isn't suitable for an adequate knowledge (a4); a fifth, when a bridge has been disassembled and reassembled elsewhere - in the original configuration or adapted to different geometric-structural schemes - and exhaustive archival sources are available (a5); the last one finally, analogous to the previous one but different due to the lack of documentary sources (a6).

Within this broad operational scenario, the solution of a first critical point appears crucial: the definition of adequate strategies in case of the unavailability of exhaustive documentary sources, especially design drawings and building site documentation.

A possible answer to this problem consists in calibrating strategies according to the taxonomic categories previously introduced: if the bridge has been demolished but adequate original pictures are available, a possible strategy is the use of image rectification as a base for the virtual reconstruction (b2) otherwise the three-dimensional model can't guarantee an adequate level of reliability but it could useful for the production of realistic images (b3) (Spallone, 2007); if a bridge has been transformed and its iron structure is partially or completely hidden, physical and geometrical data can be achieved through an extended survey or a localized survey of specific parts, recurring to destructive investigations and/or non destructive investigations such as $3 \mathrm{~d}$-scans or ultrasonic testing (b4) (Bruno et al. 2019); in case of the impossibility to complete a survey, the outcomes have to conform to (b2); in case of bridges dismantled and reassembled elsewhere, a complete or partial survey of the reassembled structure can achieve useful data for the modeling of the original architecture (b5). On the other hand, if the documentation is exhaustive it is possible to define an accurate and reliable three-dimensional model according to acquired data (b1).

A problematical question originates from the first critical point: what are the aims of the three-dimensional modeling process? If primary and secondary sources and/or survey data are exhaustive, the three-dimensional model shows an high level of reliability, so it will be a valid aid not only to the disclosure and dissemination of the original image of the bridge (c1) and urban history (c2) but also a powerful study tool for enhancing the history of engineering (c3) and the building sector (c4) and the rediscovery of construction techniques (c5) and operating methods (c6) related to the second half of the $19^{\text {th }}$ century and the early $20^{\text {th }}$ century. On the other hand, the model will be only addressed to the disclosure and dissemination, due to the low level of reliability (c1) and (c2).

The proposed methodology is summarised in the Figure 9 and has been validated testing two case studies which are particularly significant of two of six categories previously defined: the Garibaldi bridge, ascribable to the subclass (a1) and the Alari bridge, attributable to (a6).

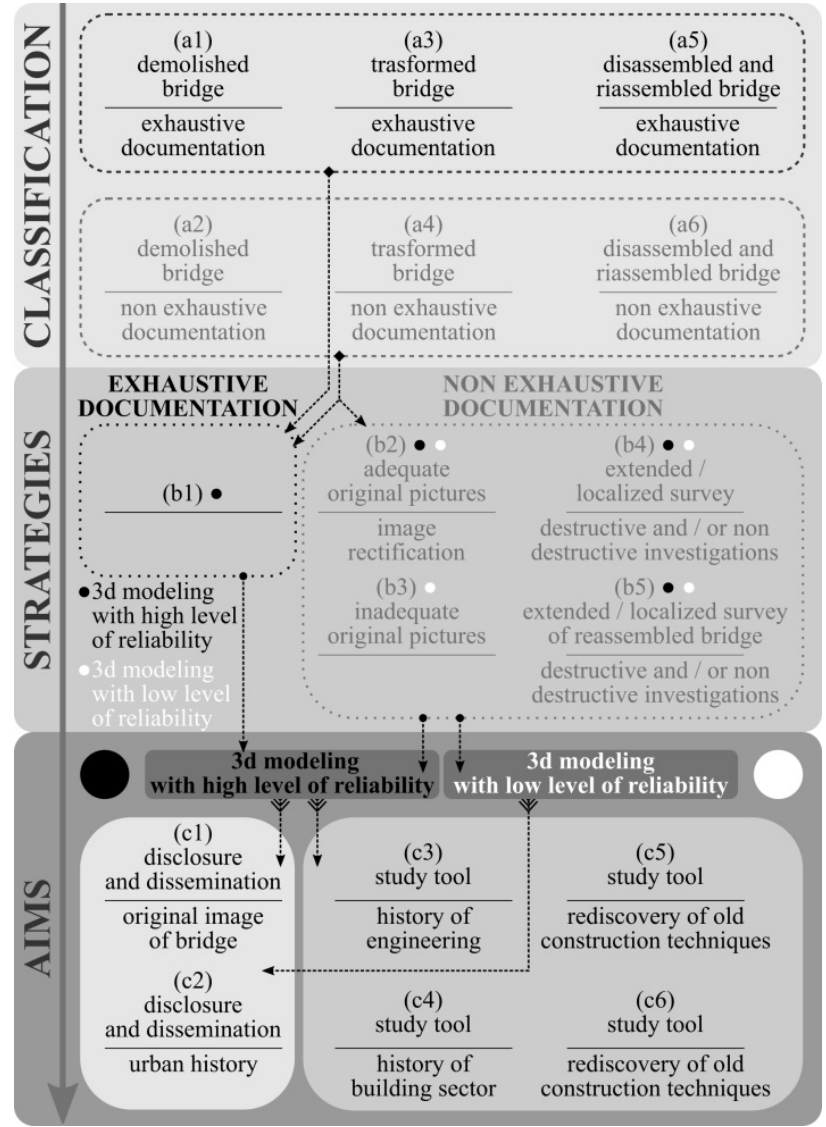

Figure 9. Diagram of the procedure

\subsection{Garibaldi Bridge}

The first of two bridges built on the far end of Tiber Island was inaugurated in 1888. The bridge, marked by two segmental metal arches sustained by a masonry pier located in the centre of the riverbed and the embankments walls on both sides, has been regularly used until 1950s, when after some load tests, the municipality decided to strengthen the structure covering the 

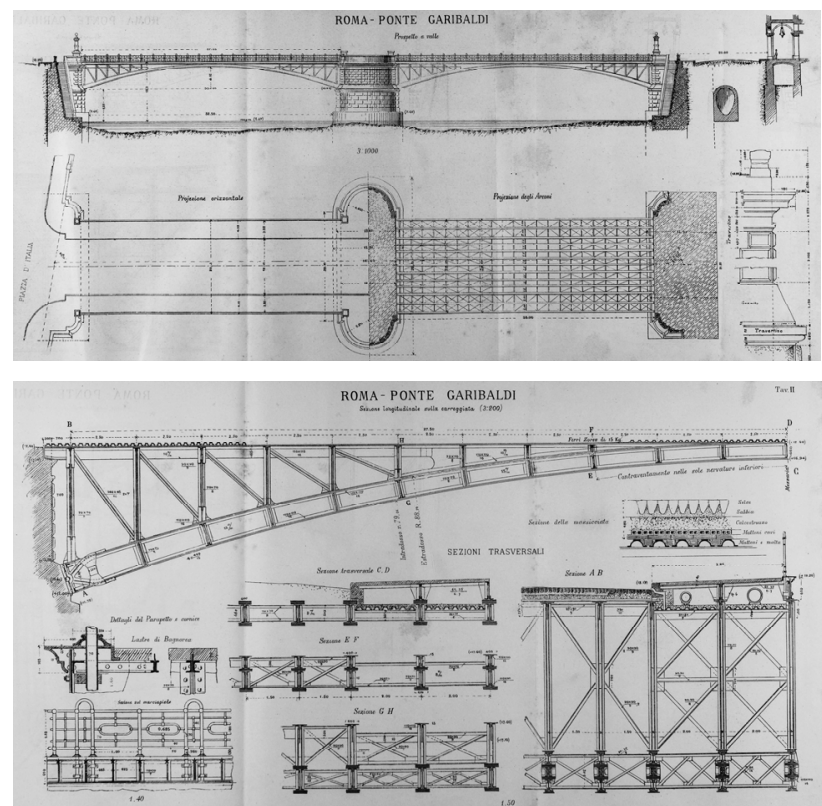

Figure 10. Detailed project of Garibadi Bridge (Bonato, 1889)

metal arches with concrete. This intervention radically modified the bridge, indeed the iron and steel structure was entirely concealed denying the view of the river perspective that was allowed through the spaces between metal components.

A research in Roman archives was carried out to retrieve the original project drawings in order to recover the original configuration of the metal arches and at Capitoline Museums Archive it was possible to view documents that detail the executive project of the bridge (Figure 10). The completeness of the drawings and project reports, which accurately reflect the geometric dimensions and the material qualities of metal components, represents an exhaustive information base for the bridge modeling, considering that the metal elements, that are no longer visible, could be detected only with invasive or destructive tests.

The bridge modeling was carried out by retracing the same steps for the construction of the bridge carried out in the workshop and on site by the Trady \& Benech industries of Savona and the company C. Zschokke \& P. Terrier. This procedure allows to shape the technological elements evaluating their congruence of assembly (Ryall et al. 2000), but it also allows to define useful operating steps to explain, at an educational level, the construction phases started in 1884. Indeed the first step consisted in the modeling of the central pier and the embankment supports located on the riverbed thanks to the compressed-air system of sinking. This parts are made of metal caissons and layers of stones like tuff, flint, travertine and red granite from Baveno, used for the imposts of the arches. The second step concerned the modeling of one of the thirteen metal arches, characterised by a span of 55 metres and a height of 5 metres (Figure 11A). The I section that taper from the bearings to the centre, is composed by iron plates, four angles and two flanges made of four overlapped plates; it is obtained singularly modeling each one of the pieces, considering their different thickness and geometry (Benvenuto, 1998). The arches are connected to the piers with bearings composed by two pinned plates and a thick steel plate bending to the cylindrical pivot, made of wrought steel and fixed into cast iron and granite blocks. The third step regarded the addition of vertical struts and diagonal braces on the upper part of the arches (Figure 11B). These pieces are made of two couples of angles, that allow the insertion of plates useful for connections with athwart

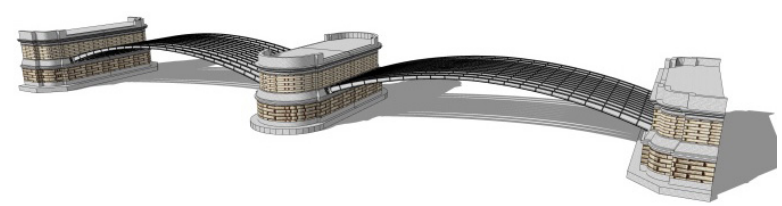

A
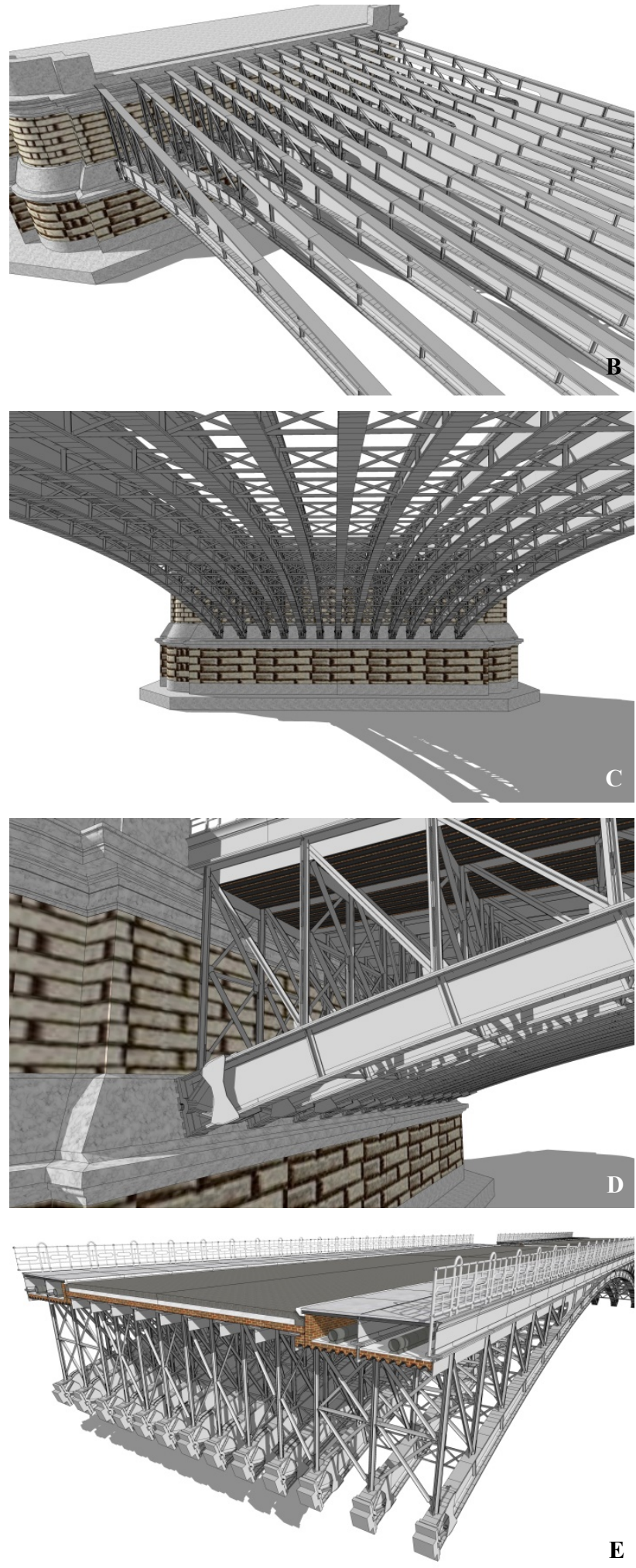

Figure 11. Steps and details of the model 
braces and the positioning of the web of the upper chord, a tapered girder which is 27,5 metres long. After the completion of supports and longitudinal elements, the fourth step regarded the modeling of the complex bracing system between the half arches, composed of cross angles or simple angles, connected with three different arrangements according to the tapered geometry of the structure (Figure 11C).

The final step considered the arrangement of the bridge deck. Zorés iron elements, $\Omega$ shaped, are put on the structure with two different directions between the carriageway and side footpaths, and they support a layer of bricks and a pouring of concrete (Masi, 1996). The carriageway is completed with a layer of cobblestones, whereas footpaths are managed with an upper metal structure that permits the passage of urban systems tubes, the connection of the parapet made of curved tubes and the support of sidewalks (Figure 11D-E). The components of the bridge can be questioned about the construction of the work, they are in fact implemented with information such as quantitative reports and photographs of the time. The insertion of the bridge model in the images related to the current context of the city allows to recover the original image of the infrastructure.

\subsection{Alari Bridge}

The construction of a new bridge on the line of Corso Vittorio Emanuele and the closure of Sant'Angelo Bridge for archaeological investigations, obliged the municipality in 1889 to request a provisional crossing of the Tiber in the area (Tuccimei, 1906). The single span steel bridge, marked by bowstring trusses simply supported by the existing side walls, remained of the most known iron bridge of the Capital, despite it lasted only twenty years. Indeed after 1911, the bridge designed by the National Company of Savigliano Fabrication Shops was demolished, but the components were used to build the new bowstring trusses and girders of the older Industry Bridge, realised in the southern part of the city under Pio IX (Figure 12). The demolition and reuse of the bridge components were fundamental for the work of virtual reconstruction of the work. The search for documentation in the archives of the capital and in the libraries that preserve the texts on the work of the Turin company, in fact, allowed only the collection of some vintage photos (Società Nazionale delle Officine di Savigliano, 1904). The presence of the construction elements of the Ponte degli Alari in the current Ponte dell'Industria has therefore allowed a verification of the geometric dimensions and of the material quality of the metal components, fundamental to proceed with an appropriate modeling that followed, as in the previous case study, the assembly phases of the bridge.

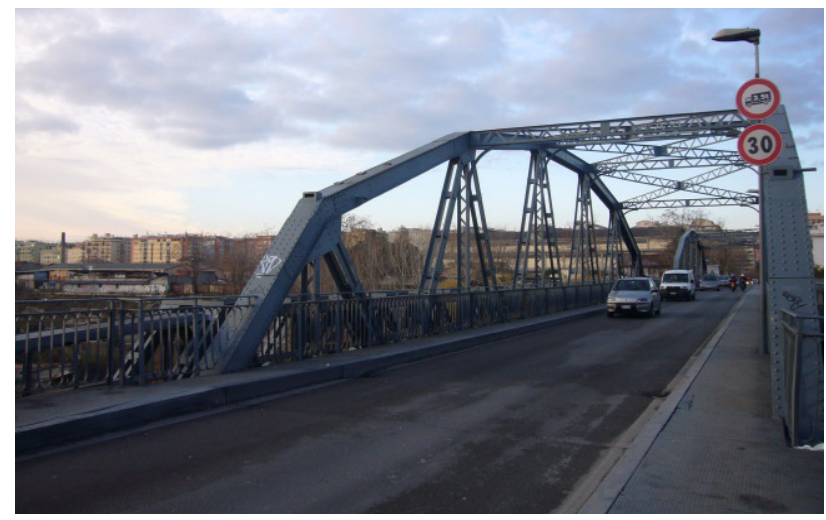

Figure 12. Industry Bridge transformed using iron elements of Alari Bridge

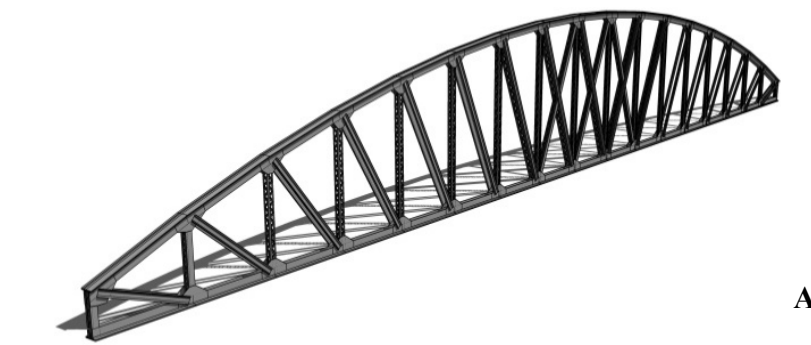

A
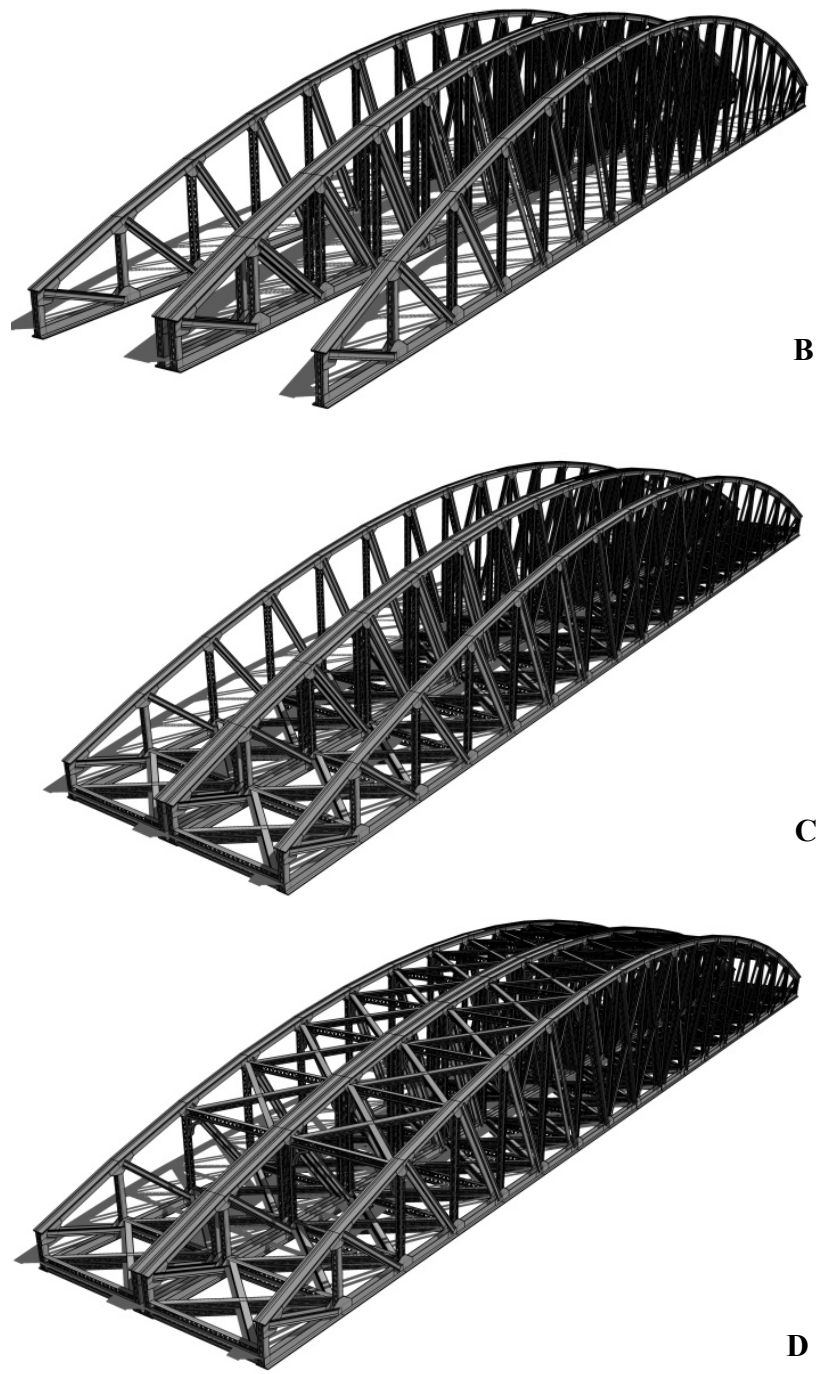

D

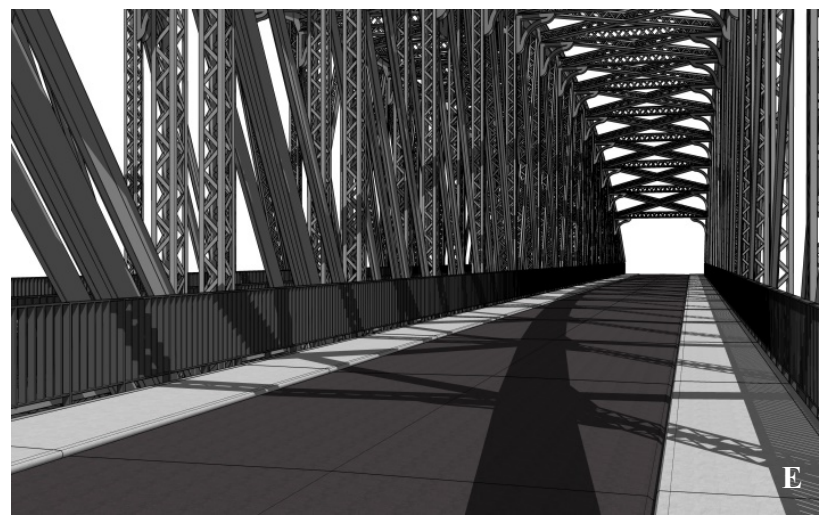

Figure 13. Steps and details of the modeling procedure of Alari Bridge 


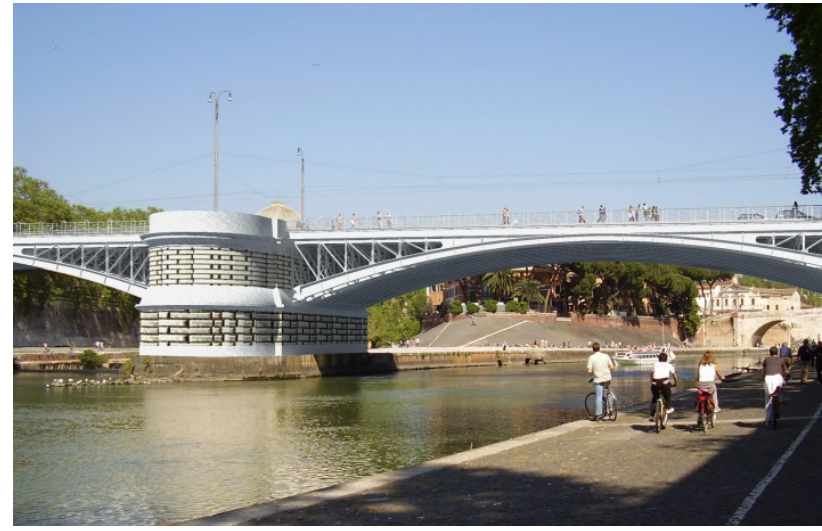

Figure 14. The virtual reconstruction of Garibaldi Bridge inserted in the area of Tiber Island

The first step included the modeling of one bowstring truss, that is 103,50 metres long and 13 metres high, drawing from below upwards. Indeed the lower chord is modelled with a couple of $T$ profiles, each one composed of a single web, angles and flanges obtained though couples of plates, shaping a hollow section which allow the insertion of the struts (Xanthakos, 1994). These elements, positioned every 6 meters, are made of angles laced by plates $\mathrm{V}$ shaped, and their heads enter into the hollow section of the curved upper chord, composed of the same profiles of the lower one. The bowstring truss is completed by diagonal braces, which are channels or laced braces, joined through trapezoidal gusset plates (Figure 13A-B).

The second step concerned the drawing of athwart braces between bowstring trusses, for which are used beams and diagonal braces. The first ones are $\mathrm{T}$ profiles with a web composed by crossed V plates, while the second ones are like the vertical struts (Figure 13C-D). The completion of the metal structure, allows in the third step the addition of the deck layers: Zorés iron elements, a concrete casting and stone finishes for the two carriageways, each one 8 metres wide, that were separately used for tram cars and for horse coaches and pedestrians. The reconstruction of the bridge recreate the "machinery" and industrial appearance given by the repetition of close iron components (Figure 13E). The location near Castel Sant'Angelo paints a lost and unusual juxtaposition between roman antiquities and modern technologies.

\section{CONCLUSIONS}

The outcomes of the present work show the potential which are inherent in the proposed methodology and open to future developments: in particular following steps will consist not only in the modeling of the remaining bridges; for example, in case of involvement of stakeholders and urban associations, one another goal could be the launch of an online platform to host outcomes of the study and offer a place of dissemination, knowledge and discussion for the rediscovery of this "weak" heritage. This work will go with a possible revision of the methodology in order to solve emerging critical points; in particular, an aspect that still appears problematic concerns those demolished bridges whose historical documentation is lacking and consists of few images. In this case the image rectification is not always suitable for a $3 \mathrm{~d}$-modeling with a high level of reliability (Marini et al. 2001). As a possible alternative, the modeling of an iron bridge could be inspired by similar experiences related to the case study, in particular those referring to common designers and/or to the same companies and/or to identical structural schemes and construction systems. Technical solutions which were proposed by the 19th century

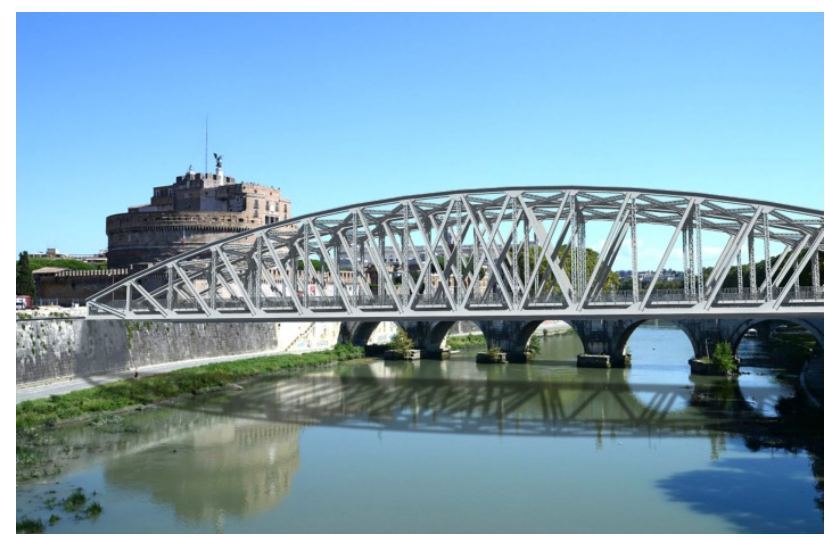

Figure 15. Virtual reconstruction of Alari Bridge placed near Castel Sant'Angelo

empiricism, were indeed repeatedly tested and used, becoming at that time a scientific-technological background which represented a spread and common knowledge for the resolution of complex problems such as the construction of a bridge.

Further developments would extend the research to the heritage of iron bridges of the Italian railway system. In this case, a limited number of companies and designers involved in the construction - in particular a Piedmontese society, the Savigliano (Pisanu and Sanjust, 2017), and a Neapolitan company IICM (Carughi, 2003) - and a limited number of structural schemes and building systems allow the use of parametric modeling, as proposed by current BIM methodologies. In particular the parametrization guaranteed by BIM, leads to a modeling process which is incredibly fast, drastically reducing times for the production of $3 \mathrm{~d}$ - models and offering the opportunity to discover an unknown national infrastructural system of the late 19th and early 20th centuries.

\section{ACKNOWLEDGEMENTS}

We want to express our gratitude to the staff of Capitoline Museums Archive (Archivio Capitolino) for the assistance in researching images and documents about Garibaldi Bridge.

\section{REFERENCES}

Apollonio, F., Fallavollita, F., Giovannini, E.C., Foschi, R., Corso, S., 2017. The Reconstruction of Drawn Architecture. Studies in Digital Heritage, 1(2), pp. 380-395.

https://doi.org/10.14434/sdh.v1i2.23243.

Archivio di Stato di Roma, 1860. Fiume Tevere: Società dei ponti sospesi, vertenza tra il Ministero del commercio e lavori pubblici ed il duca Pio Braschi Onesti e Camillo Montgolfier Boudin. In: Lavori Pubblici, Camerale II XVI - XIX, Busta 5.

Benvenuto, E., 1998. 1850-1880: Bridge-building and modern structural mechanics. In: Arch bridges: history, analysis, assessment, maintenance and repair: proceedings of the second international Arch Bridge conference, Venice, Italy, 6-9 october 1998, Balkema, Rotterdam, pp. 3-13.

Blais, F., Paquet, E., Rioux, M., Valzano, V., and Bandiera, A. Berthelot, M., Nony, N., Gugi, L., Bishop, A., and De Luca, L., 2015. The Avignon Bridge: a $3 \mathrm{~d}$ reconstruction project integrating archaeological, historical and geomorphological issues, In: The International Archives of the Photogrammetry, Remote Sensing and Spatial Information Sciences, Avila, Spain, Vol. XL-5/W4, pp. 223-227, 
https://doi.org/10.5194/isprsarchives-XL-5-W4-223-2015.

Bonato, P., 1889. Il Ponte Garibaldi sul Tevere a Roma. Tipografia Fratelli Centenari, Roma, pp. 24-25.

Bonato, P., 1891. Il nuovo Ponte Palatino in Roma. Annali della Società degli Ingegneri e degli Architetti Italiani, 2(5), pp. 307337.

Bruno, N., Coïsson, E., Diotri, F., Ferrari, L., Mikolajewska, S., Morra di Cella, U., Roncella, R., and Zerbi, A., 2019. History, geometry, structure: interdisciplinary analysis of a historical bridge, In: The International Archives of the Photogrammetry, Remote Sensing and Spatial Information Sciences, Milan, Italy, Vol. XLII-2/W11, pp. 317-323, https://doi.org/10.5194/isprsarchives-XLII-2-W11-317-2019.

Cacchiatelli, P. and Cleter, G., 1865. Le scienze e le arti sotto il pontificato di Pio IX. Stabilimento tipografico Aureli e C., Roma, Vol. 1, pp. 2-49.

Carughi, U., 2003. Alfredo Cottrau (1839-1898): l'architettura del ferro nell'Italia delle grandi trasformazioni. Electa, Napoli, pp. 100-119.

Casciato, M., 2017. The Historicity of Modern Heritage, E-flux architecture publishing platform https://www.e-flux.com /architecture/history-theory/162451/the-historicity-of-modernheritage/ (9 December 2017)

Cassani, A. G., 2014. Figure del ponte. Pendragon, Bologna, pp. $75-120$.

Cottrau, A., 1878. Album di 90 fotografie di ponti e coperture metalliche. Fotografo A. Mauri, Napoli, pp. 11-89.

Di Mascio, D., Chiuini, M., Fillwalk, J., Pauwels, P., 2016. 3D digital reconstruction of lost buildings, a first critical framing, In: Complexity \& simplicity - eCAADe 2016: Proceeding of the 34th International Conference on Education and Research in Computer Aided Architectural Design in Europe, eCAADe, Brussels, Vol. 2, pp. 511-520.

Di Mascio, D. and Pauwels., P., 2014. Migliorare la conoscenza e la gestione del patrimonio costruito storico attraverso Bim ed ontologie, In: Proceedings ofthe International Conference Preventive and PlannedConservation Monza, Mantova - 5-9 May 2014, Nardini Editore, Firenze, pp. 201-212.

D’Onofrio, C., 1980. Il Tevere : l'Isola tiberina, le inondazioni, $i$ molini, i porti, le rive, i muraglioni, i ponti di Roma. Romana Società Editrice, Roma, pp. 295-300.

Guidi, G., Russo, M., 2011. Diachronic 3D reconstruction for lost cultural heritage, In: The International Archives of the Photogrammetry, Remote Sensing and Spatial Information Sciences, Trento, Italy, Vol. XXXVIII-5/ W16, pp. 371-376, https://doi.org/10.5194/isprsarchives-XXXVIII-5-W16-3712011.

Horton, A., 1999. The Films of Theo Angelopoulos - A cinema of contemplation. Princeton University Press, Princeton, NJ USA, pp. 161-178.

Jodice, R., 1985. L'architettura del ferro: l'Italia 1796-1914. Bulzoni Editore, Roma, pp. 221-231.
Kouimtzoglou, T., Stathopoulou, E. K., Agrafiotis, P., and Georgopoulos, A., 2017. Image-based 3d reconstruction data as an analysis and documentation tool for architects: the case of Plaka Bridge in Greece, In: The International Archives of the Photogrammetry, Remote Sensing and Spatial Information Sciences, Nafplio, Greece, Vol. XLII-2/W3, pp. 391-397, https://doi.org/10.5194/isprs-archives-XLII-2-W3-391-2017.

Lévy, P., 1995. Il virtuale. Raffaello Cortina Editore, Milano, p. 57.

Marini, D., Bertolo, M., Rizzi, A., 2001. Comunicazione visiva digitale: fondamenti di eidomatica. Addison Wesley, Milano, pp. 241-326.

Masi, F., 1996. Costruire in Acciaio. Hoepli, Milano, p. 533.

Pisanu, M., and Sanjust, P., 2017. "Società Nazionale Officine Di Savigliano": The History Through Case Studies. Journal of Civil Engineering and Architecture, 11(4), pp. 1-9. doi: 10.17265/1934-7359/2017.05.000.

Ryall, M. J., Parke, G. A. R., Harding, J. E., 2000. The manual of bridge engineering, Thomas Telford, London, pp. 16-29.

Rushton, H., Silcock, D., Rogers, J., Schnabel A., 2018. The tangible and intangible: interpreting modern architectural heritage in virtual realities, In: Amps proceedings series 15, Conference Tangible - Intangible Heritage(s) - design, social and cultural critiques on the past, present and the future, London: 13-15 June 2018, Amps, London, pp. 130-140.

Quattrini, R., Pierdicca, R., Frontoni, E., and Barcaglioni, R., 2016. Virtual reconstruction of lost architectures: from the TLS survey to AR visualization, In: The International Archives of the Photogrammetry, Remote Sensing and Spatial Information Sciences, Prague, Czech Republic, Vol. XLI-B5, pp. 383-390, https://doi.org/10.5194/isprs-archives-XLI-B5-383-2016.

Società Nazionale delle Officine di Savigliano, 1904. Tipi di costruzioni metalliche. Tipografia Vincenzo Bona, Torino, pp. 3-95.

Spagnesi, G., 1976. Architettura a Roma al tempo di Pio IX 1830-1870. Cassa di Risparmio di Roma, Roma, pp. 5-25.

Spallone, R., 2007. 3D digital modeling as a method for the reconstruction of the historical image of the city: the case of piazza Bodoni in Turin (Italy) at the end of nineteenth century, In: Proceedings of the XXI International Symposium CIPA 2007: antiCIPAting the future of the cultural past : Zappeion Megaron, Athens, Greece 01-06 October 2007, Copernicus GmbH, Göttingen, Germany, pp. 685-690.

Testa, L., 2007. Il ponte dell'Industria o ponte di Ferro. In: Memorie della città industriale, Palombi Editori, Roma, pp. 3042.

Tuccimei, P., 1906. Progetto del Ponte Vittorio Emanuele sul Tevere. Il Politecnico - Giornale dell'ingegnere architetto civile ed industriale, 36(2), pp. 78-88.

Vannelli, V., 1979. Economia dell'architettura in Roma liberale: il centro urbano. Kappa, Roma, pp. 114-130.

Xanthakos, P.P., 1994. Theory and design of bridges. Wiley, New York, pp. 781-822. 